\title{
Low back pain and risk factors during the third infancy
}

\author{
Dor lombar e os fatores de risco associados \\ durante a terceira infância
}

\section{Dolor lombar y los factores de riesgo asociados durante la tercera infancia}

\section{Márcio Antônio dos Santos ${ }^{[a], ~ L u c i a n a ~ C r e p a l d i ~ L u n k e s ~}{ }^{[a]}$, Alex de Oliveira Ribeiro ${ }^{[b]}$, Alessandra de Castro Souza $[a] *$}

[a] Centro Universitário de Lavras (UNILAVRAS), Lavras, MG, Brazil

[b] Universidade Federal de Lavras (UFLA), Lavras, MG, Brazil

\section{Abstract}

Introduction: Low back pain is characterized as a pain in the area between the $12^{\text {th }}$ rib and the low gluteal fold. This pain can affect different ages. During the growth peak, the postural control system is rearranged; therefore, the maintenance and fixation of these structures is crucial for the performance of daily activities. Thus, the prevalence of low back pain and their risk factors must be investigated, so that effective preventive measures against low back pain may be taken. Objective: To investigate the prevalence of low back pain and the risks associated to it during the third infancy, that is, children aged between 6 and 12 years old. Method: A transversal and observational study with 150 children of both genders, students from private institutions of Lavras, Minas Gerais, in 2016. Questionnaires were applied in order to understand the characteristics of the sample (age, gender, school year, ethnic group, parents' educational level, means of transportation to go

* MAS: BS, e-mail: marciocruzeiro15@hotmail.com LCL: PhD, e-mail: luciana_lunkes@unilavras.edu.br AOR: PhD, e-mail: alexor@unilavras.edu.br ACS: PhD, e-mail: alesouza_28@unilavras.edu.br 
to school and situations that caused or aggravated low back pain) and their low back pain (in the last 12 months). Results: The rate of occurrence of low back pain in the senior year of school was $20 \%$. According to the chi-squared, "school year" and "ethnic group" (pardos) were the variables associated to low back pain. Sitting, mainly in front of the computer, was reported to be the main cause of the symptoms. Conclusion: Low back pain presented a prevalence of $20 \%$ with no significant difference between genders, but there was an association of low back pain and variables related to the school year and the ethnic group.

Keywords: Low Back Pain. Risk Factors. Infancy.

Resumo

Introdução: A lombalgia é caracterizada como uma dor na região entre a $12^{a}$ costela e a prega glútea inferior. Essa dor pode afetar diferentes idades. Durante o pico de crescimento ocorre uma readaptação do sistema de controle postural, com isso, é crucial a manutenção e fixação dessas estruturas para realização de atividades cotidianas. Dessa forma é necessária a investigação da prevalência de dor lombar e seus fatores de risco em crianças para que possam ser tomadas medidas preventivas efetivas no combate à lombalgia. Objetivo: Buscar a prevalência de dor lombar e fatores associados na terceira infância, ou seja, crianças com idade entre 6 e 12 anos. Método: Estudo transversal e observacional, composto por 150 crianças de ambos os gêneros, estudantes de instituições particulares de ensino na cidade de Lavras-MG no ano de 2016. Foram aplicados questionários para caracterização da dor lombar (últimos 12 meses) e da amostra (idade, gênero, ano escolar, grupo étnico, nível de ensino do responsável, transporte utilizado para ir à escola e situações desencadeantes ou agravantes da dor lombar). Resultados: A prevalência de lombalgia no último ano foi de 20\%. De acordo com o teste quiquadrado, o ano escolar e a etnia parda foram as variáveis associadas à dor lombar. A posição sentada em outra ocasião principalmente em frente ao computador foi apontada como principal atividade desencadeadora dos sintomas. Conclusão: A dor lombar apresentou prevalência de $20 \%$ sem diferença significativa entre os gêneros, mas houve associação entre lombalgia e as variáveis referentes ao ano escolar e à etnia parda.

Palavras-chave: Dor Lombar. Fatores de Risco. Infância.

\section{Resumen}

Introducción: La lumbalgia es caracterizada como un dolor en la región entre la 12a costilla y el pliegue inferior de los glúteos. Este dolor puede afectar a diferentes edades. Durante el brote de crecimiento se produce uma readaptación del sistema de control postural, con ello, es crucial el mantenimiento y la fijación de dichas estructuras para la realización de actividades cotidianas. De esta manera, es necesaria la investigación de la prevalencia de dolor lumbar y susfactores de riesgo para que se puedan tomar lãs medidas preventivas más efectivas en el combate a la lumbalgia. Objetivo: Buscar la prevalencia de dolor lumbar y factores asociados en la tercera infancia, o sea, los niños con edad entre 6 y 12 años. Método: Estudio transversal y observacional, compuesto por 150 niños de ambos géneros, estudiantes de instituciones privadas de enseñanza en la ciudad de Lavras-MG en el año 2016. Fueron aplicados cuestionarios para la caracterización del dolor lumbar (últimos 12 meses) y de la muestra (edad, género, año escolar, grupo étnico, nivel de educación del responsable, tipo de transporte utilizado para ir a la escuela y situaciones desencadenantes o agravantes del dolor lumbar). Resultados: La prevalencia de la lumbalgia en el último año fue de $20 \%$. De acuerdo con la prueba de ji-cuadrado, el año escolar y la etnia parda fueron las variables asociadas a dolor lumbar. La posición sentada en outra ocasión, principalmente frente a la computadora fue señalada como la principal actividad desencadenadora de los síntomas. Conclusión: El dolor lumbar presentó prevalência del 20\%, sin diferencia significativa entre los géneros, pero huboa sociación entre la lumbalgia y las variables correspondientes al año escolar y a la etnia parda.

Palabras clave: Dolor Lumbar. Factores de Riesgo. Infancia. 


\section{Introduction}

Low back pain is characterized as a pain in the area between the $12^{\text {th }}$ rib and the low gluteal fold, either with or without radiating into the leg. This pain, either acute or chronic, provokes an unpleasant experience regarding both the sensorial and emotional aspects. This injury results from a tissue injury that generates incapacity to work and might provoke absenteeism, which causes expenses to the health system and the State [1-4].

Several studies [5-8] developed in the last few years confirmed that low back pain (LBP), which usually affects adults, can also affect children and adolescents, since the prevalence of low back pain in school children is almost the same as that found in adults $[9,10]$. In Brazil, a predominance of almost $80 \%$ was found in the 166 participants aged between 11 and 18 in a private school in Piaui State [7]. Another study developed with 80 volunteers that were students in the $5^{\text {th }}$ and $6^{\text {th }}$ years in Portugal, whose age range was $10-12$ years old, a $46.3 \%$ prevalence was found [8]. In Japan, an 83.4\% prevalence of low back pain was seen in adults aged 20 to 79 years old of both genders [9]. In Germany, around $67 \%$ of the interviewees in the age range 18-75 years old reported low back pain [10].

During the school period, the transition from infancy to adolescence occurs resulting in a growth peak and changes regarding cognitive and social issues related to the individual's autonomy and self-steem [11]. Thus, each new experience of the child provokes a rearrangement of the postural control systems. Therefore, the development and maintenance of proper posture are very important for the accomplishment of the activities of daily living (ADLs) [12].

Some of the children's daily activities might be affected as a consequence of recurrent or constant low back pain endured for a certain period [13]. For this reason, investigating the prevalence of LBP and its risk factors is necessary to identify preventive measures and effective interventions [14], to improve these children's quality of life. High prevalence of back chronic pain is associated to reduction in the quality of life [15]. Low back pain is multifactorial, including risk factors such as gender, obesity, sedentary habits, body weight and the way the backpack is carried [4]. Therefore, both the pain and its risk factors when identified in infancy have better chances to be prevented from developing along the individual's life.
The objective of this study was to investigate the prevalence of low back pain in the third infancy, that is, children aged between 6 and 12 years old, and its possible association to sociodemographic factors, type of school transportation and body mass index (BMI).

\section{Methodology}

The study was submitted to and approved by the Research Ethics Committee of the Lavras University Center (CAAE 49975615.1.0000.5116). This is a transversal observational study, based on a representative sample of the population of two private schools in Lavras, Minas Gerais. The data collection was authorized by the children's parents or guardians. The sample comprised 150 children and the volunteers were selected following the inclusion criteria: both genders, age range from 6 to 12 years old, students from the $1^{\text {st }}$ to the $7^{\text {th }}$ year presenting normal cognition and absence of musculoskeletal alterations, mainly those associated to fracture. Children that did not come on the day of the data collection, omitted some answer and/or could not answer some items of the questionnaire would be excluded from the study. However, there was no need to exclude any of the volunteers.

The data was collected individually in a proper room during a visit to the school. Two questionnaires were used to collect the data needed during the study, both questionnaires had been validated for the Brazilian population and widely used. The interviewer was previously trained.

The first questionnaire was used to characterize low back pain, based on the methodology by

Bogas [8] and presented the following question: "Have you ever had pain in the shaded area (low back region) of the drawing that lasted one day or more?". The quantification of the low back pain, when existing, was carried out by employing a faces pain scale in which 0 represented minimum pain and 5 maximum pain [6]. The second questionnaire included questions associated to sociodemographic characteristics (age, gender, ethnicity and parents' education level), type of transportation used to go to school (on foot, by bike, by bus, by car, any other), low back pain and triggering positions [16]. This questionnaire was adapted by removing the item "paid work" due to the age of the volunteers. In addition, weight $(\mathrm{kg})$ and height $(\mathrm{m})$ of the children were recorded for later calculation of BMI. 
The dependent variable non-specified LBP was anatomically defined as any pain occurring between the $12^{\text {th }}$ rib and the inferior gluteal fold without radiating to the lower limbs $[1,2]$. To increase the accuracy of data collection, this definition was complemented with the factor 24-hour minimum duration of symptoms, which would exclude situations of low back pain due to fatigue that might be solved in a few hours ${ }^{17}$.

Statistical analysis of the data collection was carried out for validation and later descriptive and bivariate analysis. The type of transport, ethnicity and parents' level of education were grouped for the bivariate analysis, conforming the categories presented into tables aiming at obtaining suitable groups for the hypotheses test.

The descriptive analysis showed absolute and relative frequency distributions for the categorical variables, mean and standard deviation for continuous variables. In the analytical approach, bivariate analysis was carried out with calculation of the reasons of prevalence (RP) with confidence intervals (CI) and chi-square test for the nominal variables, considering significant the associations with $\mathrm{p}<0.05$.

\section{Results}

The final sample comprised 150 children, since none of the volunteers selected dropped the study. Regarding gender, there was a slight predominance of female volunteers (50.7\%). From these, most were in the white ethnic group (80\%), followed by dark (parda) (14.70\%) and black (5.30\%). In relation to the school year, most of the sample included students in the third year (22\%), fifth year (22\%) and fourth year $(20 \%)$. There was a considerable number of students from the seventh year $(10.70 \%)$, from the sixth year $(10 \%)$, from the first year $(8.70 \%)$ and from the second year $(6.70 \%)$. The BMI results showed that most of the individuals were thin (52.70\%), followed by normal BMI $(43.30 \%)$ and obese $(4 \%)^{10}$. As for the parents' level of education, most had completed higher education (50.70\%), followed by those who completed high school $(26.70 \%)$ and those who did not finish their university course $(20 \%)$, other levels amounted $2.7 \%$. The variable transportation showed that most students were driven to school (64\%), followed by those who went by bus (18.70\%), on foot $(10.70 \%)$ and by motorcycle $(6.70 \%)$.

The prevalence of low back pain among the volunteers was $20 \%(n=30)$. The level of pain measured using the pain faces scale [18] resulted in a relatively low mean (2.03 between 0 and 5). Among those who reported pain in the last year, $80 \%$ related it to the sitting position (at home, watching $\mathrm{TV}$, at school and in other situations), followed by the physical education class (20\%).

No statistically significant difference was found between genders in those who reported low back pain $(p=0.935)$. There was correlation between the variables low back pain and school year $(p=0.024)$, with higher prevalence of low back pain in the initial levels of education [Table 1].

Table 1 - Prevalence of low back pain according to gender and school year

\begin{tabular}{|c|c|c|c|}
\hline \multirow{2}{*}{ GENDER } & \multicolumn{2}{|c|}{ LOW BACK PAIN } & \multirow{2}{*}{$p$ value } \\
\hline & Absence & Presence & \\
\hline Male & $59(79.7 \%)$ & $15(20.3 \%)$ & \multirow{2}{*}{0.935 (NS) } \\
\hline Female & $61(80.3 \%)$ & $15(19.7 \%)$ & \\
\hline \multirow{2}{*}{ SCHOOL YEAR } & \multicolumn{2}{|c|}{ LOW BACK PAIN } & \multirow{2}{*}{$p$ value } \\
\hline & Absence & Presence & \\
\hline First year & $8(61.5 \%)$ & $5(38.5 \%)$ & \multirow{7}{*}{$0.024^{*}$} \\
\hline Second year & $6(60.0 \%)$ & $4(40.0 \%)$ & \\
\hline Third year & 32 (97.0\%) & $1(3.0 \%)$ & \\
\hline Fourth year & $24(80.0 \%)$ & $6(20.0 \%)$ & \\
\hline Fifth year & 24 (72.7\%) & $9(27.3 \%)$ & \\
\hline Sixth year & 11 (73.3\%) & $4(26.7 \%)$ & \\
\hline Seventh year & $15(93.8 \%)$ & $1(6.3 \%)$ & \\
\hline
\end{tabular}

Note: Chi-square test - significant at $5 \%$ probability level; NS: Chisquare test - not significant at $5 \%$ probability level.

There was correlation between the variables low back pain and ethnic group $(\mathrm{p}=0.024)$, with higher prevalence in individuals considered dark (pardos), a considerable value for those considered black and significantly lower in the white ones. According to the results obtained regarding parents' level of education, the percentage values found were not sufficient to associate it to the children's low back pain [Table 2].

When evaluating the relation between the type of transportation to go to school and BMI, no correlation was found with low back pain ( $\mathrm{p}=0.288$ and $\mathrm{p}=0.163$, respectively). Regarding transportation, children that walked to school showed higher prevalence of low back pain $(37.5 \%)$, when compared to those that went by car $(16.7 \%)$. As for BMI, volunteers that were below normal weight and those that presented normal weight showed similar values, unlike those that were overweight [Table 3]. 
Table 2 - Prevalence of low back pain according to ethnic group and parents' level of education

\begin{tabular}{|c|c|c|c|}
\hline \multirow{2}{*}{ ETHNIC GROUP } & \multicolumn{2}{|c|}{ LOW BACK PAIN } & \multirow{2}{*}{$p$ value } \\
\hline & Absence & Presence & \\
\hline White & $101(84.2 \%)$ & $19(15.8 \%)$ & \\
\hline Black & $6(75.0 \%)$ & $2(25.0 \%)$ & $0.024^{*}$ \\
\hline Dark & $13(59.1 \%)$ & $9(40,9 \%)$ & \\
\hline \multirow{2}{*}{ SCHOOLING } & \multicolumn{2}{|c|}{ LOW BACK PAIN } & 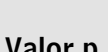 \\
\hline & Absence & Presence & vivi \\
\hline $\begin{array}{l}\text { Incomplete elementary } \\
\text { school }\end{array}$ & $1(50.0 \%)$ & $1(50.0 \%)$ & \\
\hline $\begin{array}{l}\text { Complete elementary } \\
\text { school }\end{array}$ & $1(100.0 \%)$ & $0(0.0 \%)$ & \\
\hline Incomplete high school & $1(100.0 \%)$ & $0(0.0 \%)$ & 0.741 \\
\hline Complete high school & $33(82.5 \%)$ & 7 (17.5\%) & (NS) \\
\hline $\begin{array}{l}\text { Incomplete higher } \\
\text { education }\end{array}$ & $22(73.3 \%)$ & $8(26.7 \%)$ & \\
\hline $\begin{array}{l}\text { Complete higher } \\
\text { education }\end{array}$ & $62(81.6 \%)$ & $14(18.4 \%)$ & \\
\hline
\end{tabular}

Note: Chi-square test - significant at $5 \%$ probability level; NS: Chisquare test - not significant at $5 \%$ probability level.

Table 3 - Prevalence of low back pain according to the type of transportation used to go to school and BMI

\begin{tabular}{lccc}
\hline TYPE OF & \multicolumn{2}{c}{ LOW BACK PAIN } & \multirow{2}{*}{ p value } \\
\cline { 2 - 3 } TRANSPORTATION & Absence & Presence & \\
\hline Car & $80(83.3 \%)$ & $16(16.7 \%)$ & \\
Motorcyle & $8(80.0 \%)$ & $2(20.0 \%)$ & \multirow{2}{*}{$0.288($ NS) } \\
Bus & $22(78.6 \%)$ & $6(21.4 \%)$ & \\
Walking & $10(62.5 \%)$ & $6(37.5 \%)$ & \\
\hline \multirow{2}{*}{ BMI } & \multicolumn{2}{c}{ LOW BACK PAIN } & \multirow{2}{*}{ p value } \\
\cline { 2 - 3 } & Absence & Presence & \\
\hline Below normal & $65(82.3 \%)$ & $14(17.7 \%)$ & \\
Normal & $52(80.0 \%)$ & $13(20.0 \%)$ & $0.163($ NS) \\
Overweight & $3(50.0 \%)$ & $3(50.0 \%)$ & \\
\hline
\end{tabular}

Note: Chi-square test - not significant at $5 \%$ probability level.

\section{Discussion}

In the current literature, works with children in the third infancy, mainly in the initial years ( 6 and 7 years old) are relatively scarce, mainly in the Brazilian population. Therefore, this study is novel and has great importance and extreme relevance due to the need of effective interventions from the beginning of the school years. The consequences of low back pain in children are worrying, among them are the flexibility, increase in the chances of injuries and muscular pain [19].
The prevalence of low back pain in this study was $20 \%(\mathrm{n}=30)$. Research developed in Denmark pointed out 33\% low back pain incidence in 8 to 10 -year-old children [20]. In Malta, a study with 8 to 13 -year-old schoolchildren resulted in a $32 \%$ prevalence [21]. In Portugal, $29.7 \%$ of the volunteers aged between 10 and 16 years old reported the presence of low back pain in the previous year [22]. In Brazil, a study carried out in a private school in Porto Alegre (RS) presented a 31.6\% low back pain index in a group of 770 students aged 7 to 17 years old, which showed that the comparison between prevalence values is difficult due to the different low back pain definitions found [23]. In a study developed in Canoas (RS) with 162 youngsters aged 9 to 15 years old revealed a $11.5 \%$ prevalence of low back pain [20]. Research carried out in Bauru (SP) with 1236 schoolchildren aged 11 to 14 years old found a $19.5 \%$ prevalence of low back pain ${ }^{4}$.

In the group that reported low back pain, most of the interviewees mentioned having felt some discomfort when sitting on other occasions, mainly when using the computer/laptop. This position when adopted for long periods of time is known to deposit the whole load on the invertebral discs [24]. Studies have confirmed that the sitting posture might provoke changes in the body structures, resulting in situations such as low back pain, increase in the pressure on invertebral discs, inflammation of osteomuscular structures with associated pain symptoms, among others [10]. Many of the activities carried out by schoolchildren, such as games and research associated to the use of computers in the sitting position, favor the occurrence of low back pain in the third infancy.

The occurrence of low back pain in children might be associated to alterations resulting from bad posture habits and the repeated exposure to small overloads [25].

The International Classification of Functioning, Disability and Health in its extended version for children and young people is considered a starting point regarding the description of children's participation in daily life. Participation here can be defined as the "involvement of an individual in life situations", this can be influenced by health conditions, body and structural functions, activities and other factors associated to this context [26, 27]. From this description, when anatomic structures (articulations, muscles and ligaments) are not able to 
adjust to the unsuitable postures adopted in the daily routine, mainly the lumbar spine, the individual might suffer discomfort, pain or functional disabilities [28]. Therefore, it is vital to understand the existing interrelation between structural and functional changes in the individual's context, considering that low back pain might impact a child's life.

No association was found between low back pain and gender, both presented very similar values. Studies have confirmed that based on body dimensions (weight and height) corresponding to the beginning of the third infancy, there is no significant difference between boys and girls [29]. In an analysis with 126 students aged between 10 and 15 years old, a 79.4\% prevalence of low back pain was found in girls and $57.1 \%$ in boys. According to that author, this occurs because during the puberty (a period corresponding to both infancy and adulthood, usually stretching from 12 to 18 years of age [30]) women develop earlier than men [16]. Consequently, the adaptation to tiring physical activities is lower, there is increase in the frailty of articulations, higher sensitiveness in several painful conditions, and the pain perception can be influenced by hormonal factors resulting from the puberty ${ }^{31}$. In addition to the physiological equivalence between genders in the third infancy, some activities developed at home, at school and in recreation are also similar among children, which might justify the similar results between genders.

There was correlation between the presence of low back pain and the children's school level $(p=0.024)$. According to the data, students in the first and second year of elementary school presented higher indices of low back pain. On the other hand, a study developed in the municipality of Uruguaiana/ RS found prevalence of low back pain in older students. The explanation given by that author was the accumulation of overload on the backbone, among other factors, such as the transportation of heavy objects, contributing to the appearance of alterations that might harm the lumbar region [31]. There is a general belief that at this phase the children's musculoskeletal structures are not mature enough to support wrong postures or overload for a long time.

In relation to ethnicity, the results pointed out some correlation between low back pain and the dark (pardos) ethnicity $(\mathrm{p}=0.024)$. Through odds ratio (OR), which is a measure of association, this ethnicity has 3.5 times higher chance to report low back pain $(\mathrm{OR}=$ 3.5275 , IC $95 \%, \mathrm{p}<0.05)$. A recent study also reported higher prevalence of low back pain in this ethnic group when compared to others (white, black), which occurs due to the low schooling rate and higher exposure to physical effort of this population, in addition to lower chances of access to health services [32]. Since the children taking part in this study present the same schooling level, it is not possible to confirm that this factor might be related to the ethnic group and the presence of low back pain in these volunteers. Other factors, mainly biomechanical might be associated.

When the level of education of the parents was analyzed, no correlation was found with low back pain in the volunteers $(p=0.741)$. However, those that reported incomplete high school or lower level of education were only $2.7 \%$ of the total sample, which might be considered a limitation of this study. Practically two thirds of the Brazilian population in the productive age range present less than 12 years of formal education [33]. According to information gathered in a study, individuals with higher education levels present higher ability to prevent and deal with low back pain. Thus, parents with a good level of education might better prevent low back pain in their children [34].

As for the means of transportation, around a third of the students that presented low back pain go to school on foot. A possible hypothesis is that due to the backpack weight, their spine has to support a higher load for long periods of time, which might result in undesired alterations to the lumbar spine, such as pain [35]. A study carried out with 1,597 schoolchildren aged 11-16 years old reported that, even with the use of backpacks with symmetrical shoulder straps (considered suitable), the students still presented high incidence of back pain [9].

The body mass index did not present correlation with low back pain $(p=0.163)$. One of the possible explanations might be the low number of children exposed to overload present in the sample ( $4 \%$ in total), since there is a strong link between low back pain and high BMI. This correlation exists due to the fact that the high body mass index generates greater load deposition on the invertebral discs, predisposing the individual to the low back pain risk [36]. Confirming such hypothesis, a study carried out in Norway, proved that obesity and weight excess are factors that predispose both men and women to chronic low back pain [37]. The increase in weight might generate fatigue and develop compensations in some of the body structures, resulting in pain in the lumbar region.

One limitation of this study is the fact that the sample only included students from private schools, 
since the situation in public schools might be diverse. Therefore, further studies are needed including representative samples of the population of different categories of educational institutions.

\section{Conclusion}

Although many studies focusing on low back pain have been developed worldwide, it is still very important to explore its prevalence and risk factors in the early stages of life, thus enabling the development of more efficient strategies of prevention and interference.

This study allowed the conclusion that the prevalence of schoolchildren that report low back pain in the senior year was $20 \%$, without significant difference between genders. This pain is associated to the time spent in a sitting position, dark (pardos) ethnicity and school year. Studies approaching this theme are still scarce in the literature, since nowadays there is a high percentage of low back pain in infancy. Therefore, more studies are needed to investigate how much can low back pain influence children's activities of daily life, so that prevention measures and early treatment can be provided to improve these individuals' physical and mental well-being.

\section{Acknowledgements}

The author is thankful to the volunteers of this study for being available and committed to the project. To the Centro Universitário de Lavras - UNILAVRAS (University Center of Lavras) for the support provided to this research and to the Fundação de Apoio à Pesquisa de Minas Gerais (FAPEMIG) (Research Support Foundation) for the financial support.

\section{References}

1. Meucci RD, Fassa AG, Paniz VM, Silva MC, Wegman $\mathrm{DH}$. Increase of chronic low back pain prevalence in a médium sized city of southern Brazil. BMC Musculoskelet Disorders. 2013;(14):155.

2. Festas C. Dor lombar em crianças e adolescentes, estudo de prevalência, fatores de risco e intervenção para a educação postural [dissertation]. Porto: Universidade do Porto; 2010.
3. Stefane T, Munari AS, Marinovic A, Hhortense P. Dor lombar crônica: intensidade de dor, incapacidade e qualidade de vida. Acta Paul Enferm. 2013;26(1):14-20

4. De Vitta A, Piza NT, Simeao SF, Ferreira NP. Prevalence of lower back pain and associated factors in students. Cad Saude Publica. 2011;27(8):1520-8.

5. Noll M, Fraga RA, Rosa BN, Candotti CT. Fatores de risco associados à intensidade de dor nas costas em escolares do município de Teutônia (RS). Rev Bras Cienc Esporte. 2016;38(2):124-1.

6. Macedo RB, Sousa NF, Santos JV, Rodrigues AM, Cumming SP, Lima AV, et al. Quality of life, school backpack weight, and nonspecific low back pain in children and adolescents. J Pediatr (Rio J). 2015;91(3):263-9.

7. Ernani D, Cavalcante A, Nunes C, Viana DL, Valmor F, Cunha M, et al. Dor lombar em adolescentes: um rastreamento escolar. Rev Bras Crescimento Desenvolv Hum;2014;24(3):1-6.

8. Bogas R. Dor lombar em crianças e adolescentes, estudo de prevalência [dissertation]. Porto: Universidade Fernando Pessoa; 2012.

9. Fuji T, Matsudaira K. Prevalence of low back pain and factors associated with chronic disabling back pain in Japan. Eur Spine J. 2013;22(2):432-8.

10. Schmidt CO, Raspe H, Pfingsten M, Hasenbring M, Basler HD, Eich W, et al. Back pain in the German adult population: prevalence, severity, and sociodemographic correlates in a multiregional survey. Spine. 2007;32(18):2005-11.

11. Do Valle MB, Noll M, Candotti CT. Prevalência de dor nas costas e fatores associados em escolares do ensino fundamental de uma escola militar: um estudo transversal. R Bras Ci e Mov: RBCM. 2016;24(2):26-34.

12. Dias TB, Mejia DP. A incidência de escoliose em crianças de 12 a 15 anos de idade escolar. 2012 [cited 2016 Oct 20]. Available from: http://bit. ly/2WK1v7M.

13. Nunes J. Prevalência de dor lombar em pessoas que trabalham na postura sentada. Rev UNILUS Ens Pesq. 2016;55(13):67-75. 
14. Silva MR, Badaró AF, Dall'Agnol MM. Low back pain in adolescente and associated factors: a cross sectional study with schoolchildren. Braz J Phys. Ther. 2014;18(5):402-9.

15. Romero DE, Santana D, Borges P, Marques A, Castanheira D, Rodrigues JM, et al. Prevalência, fatores associados e limitações relacionados ao problema crônico de coluna entre adultos e idosos no Brasil. Cad Saude Publica. 2018;34(2):1-15.

16. Sjolie AN. Active or passive journeys and low back pain in adolescents. Eur Spine J. 2003;12(6):581-8.

17. Jones GT, Macfarlane GJ. Predicting persistent low back pain in school children: a prospective cohort study. Arthritis Rheum. 2009;61(10):1359-66.

18. Herr KA, Mobily T, Kohout FJ, Wagenaar D. Evaluation of the faces pain scale for use with elderly. Clin J Pain. 1998;(14):29-38.

19. Bortolini AC, Jaeger DB, Siqueira OD, Crescente LAB, Garipp DC. Associação entre dores nas costas, flexibilidade e força/ resistência abdominal em criança e adolescentes. Cinergis. 2016;17(3):231-4

20. Wedderkopp N, Leboeuf YDE C, Andersen LB, Froberg $\mathrm{K}$, Hansen HS. Back pain reporting pattern in a Danish population-based sample of children and adolescents. Spine. 2001;26(17):1879-83.

21. Spiteri K, Busuttil ML, Aquilina S, Gauci D, Camilleri E, Grech V. Schoolbags and back pain in children beteen 8 and 13 years: a national syudy. Br J Pain. 2017;17(2):81-6.

22. Borges SA, Mesquita CC, Sousa A. Prevalência de dor lombar não específica em alunos da Escola EB 2/3 de Santa Marinha. Anais I Congresso Internacional da Saúde Gaia-Porto; 23-25 setembro 2010; Porto, Portugal. Porto, IPP; 2010.

23. Lemos AT, Santos FR, Moreira RB, Machado DT, Braga FC, Gaya AC. Ocorrência de dor lombar e fatores associados em crianças e adolescentes de uma escola privada do sul do Brasil. Cad Saude Publica. 2013;29(11):2177-85.
24. Souza AV, Cardoso JP, Rocha SV, Amorim CR, Carneiro LR. V, Vilela AB. Nível de atividade física e lombalgia entre funcionários de uma instituição de ensino. Rev Bras Promoç Saude. 2011;24(1):199-206.

25. Filho D, Viana C, Cabral M, Cunha F, Pacheco F, Brito A, et al. Dor lombar em adolescentes: um rastreamento escolar. Rev Bras Crescimento Desenvolv Hum. 2014:24(3):347-53.

26. Word Health Organization. International Classification of Functioning, Disabilty and Health: Version of Children and Youth. Geneva: World Health Orgnization; 2007.

27. Chien CW, Rodger S, Copley J, Skorka K. Comparative contet review of childre's participation measures using the international classification of functioning, disability and health-children and youth. Arch Phys Med Rehabil. 2014;95:141-52.

28. Detsch C, Luz A, Candotti C, Oliveira D, Lazaron F, Guimarães L, et al. Prevalência de alterações posturais em escolares do ensino médio em uma cidade no Sul do Brasil. Rev Panam Salude Publica. 2007:21(4):231-8.

29. Ferreira M,Bohme MT. Diferenças sexuais no desempenho motor de crianças: influência da adiposidade corporal. Rev Paul Educ Fis. 1998; 12(2):181-92.

30. Jardim FA, Campos TS, Mata RN, Firme MPR. Doenças sexualmente transmissíveis: a percepção dos adolescentes de uma escola pública. Cogitare Enferm. 2013;18(4):663-8.

31. Graup S, Araújo BM, Bergann GG. Prevalência de dor lombar inespecífica e fatores associados em adolescentes de Uruguaiana/RS. Rev Bras Ortop. 2014;49(6):661-7.

32. Oliveira MM, Andrade SS, Souza CA, Ponte JN, Szwarcwald CL, Malta DC. Problema crônico de coluna e diagnóstico de distúrbios osteomusculares relacionados ao trabalho (DORT) autor referidos no Brasil: pesquisa nacional de saúde, 2013.Epidemiol Serv Saude. 2015;24(2):287-96. 
33. Salvetti MD, Pimenta CA, Braga PE, Correa CF. Incapacidade relacionada à dor lombar crônica: prevalência e fatores associados. Rev Esc Enferm USP. 2012;46(Esp):16-23.

34. Ponte C. Lombalgia em cuidados de saúde primários: sua relação com características sociodemográficas. Rev Port Clin Geral. 2005;(21):259-67.

35. Mendes RR. Relação entre as alterações posturais ocasionadas pelo excesso de peso da mochila escolar e sua incidência no sistema locomotor de escolares do município de Guarabira [undergraduate dissertation]. Guarabira: Univesidade Aberta do Brasil; 2014.

36. Cardoso RK, Rombaldi AJ, Silva MC. Osteomuscular disorders and associated factors among solid waste collectors of two middle-sized cities from the South of Brazil. Rev Dor. 2014;15(1):13-6.
37. Garavaglia MM, Mak TH, Cusiamano MD, Rigamonti A, Crescini C, Mccredy VA, et al. Body mass index as a risk factor for increased serum lactate during craniotomy. Minerva Anestesiol. 2013;79(10):1132-9.

Recebido em 06/12/2017 Received in 12/06/2017 Recibido en 06/12/2017

Aprovado em 10/01/2019 Approved in 01/10/2019

Aprobado en 10/01/2019 